\title{
Effect of Photoperiodism on Enzymatic Responses of Sugarcane
}

\author{
Marco A. Tión \\ INTRODUCTION
}

It has been suggested by several investigators that there is a definite relationship between the photoperiodic responses of the plants and their enzymatic systems (1) ${ }^{2}$ (2) (7) (8) (9) (10) (11) (13). It has also been demonstrated (15) that maleic hydrazide delays the blossoming of some plants and (5) that it affects the respiratory activity of the plants through the partial inactivation of one or more dehydrogenases. Since the effect of maleic hydrazide on the delay of blooming seems to be similar to that produced by additional periods of light upon short-day plants, it was thought wise to investigate the possible effect of photoperiodism upon the enzymatic relations of sugarcane plants, particularly upon the dehydrogenases.

\section{EXPERIMENTAL PROGEDURE}

In this investigation meristematic tissue of sugarcane plants which had received 2 hours of additional light every night for the period May 15 to September 24, and which did not bloom; and of similar tissue samples from control plants which bloomed normally, were used for the preparation of extracts. The dehydrogenase activity of the extracts of these tissues was determined colorimetrically by the triphenyltetrazolium chloride method (3). For quantitative determinations, a concentration curve (fig. 1) was prepared by using standard solutions containing $1,2,4,6,8$, and $10 \mu \mathrm{g}$. of triphenyl formazan per milliliter of solution. These solutions were prepared by dissolving in acetone crystals of the tryiphenl formazan previously synthesized by the method of Mattson et al. (12).

Points on the standard curve were determined by measurements of the optical density at the $490-\mathrm{m} \mu$ absorption maximum using a Coleman Universal Model 14 spectrophotometer.

The meristematic parts of the sugarcane were dispersed in a Waring blendor with acetone for 5 minutes. The filtrate was discarded and the remaining solid matter was placed in a desiccator for 2 weeks until it was completely dry. Ten grams of the dry material from the plants subjected to each of the treatments, i.e., additional periods of light and natural daylength, were blended separately in a Waring blendor for 3 minutes with

${ }_{1}$ Associate Plant Physiologist, Agricultural Experiment Station, University of Puerto Rico, Río Piedras, P. R.

${ }_{2}$ Numbers in parentheses refer to Literature Cited, p. 20-1. 
$20 \mathrm{ml}$. of phosphate buffer of $\mathrm{pH}$ 7.4. The blended material was squeezed through six layers of cheesecloth and finally filtered through a No. 40 Whatman filter paper. One milliliter of the filtrate from the extraction of the meristematic tissues of the plants subjected to the extended photoperiods was placed in each of six small test tubes. To each of these tubes were also added $0.5 \mathrm{ml}$. of $0.2 \mathrm{M}$ sodium succinate, $1 \mathrm{ml}$. of the phosphate buffer, $2 \mathrm{ml}$. of distilled water, and $0.5 \mathrm{ml}$. of 0.5 -percent $2,3,5$-triphenyl-

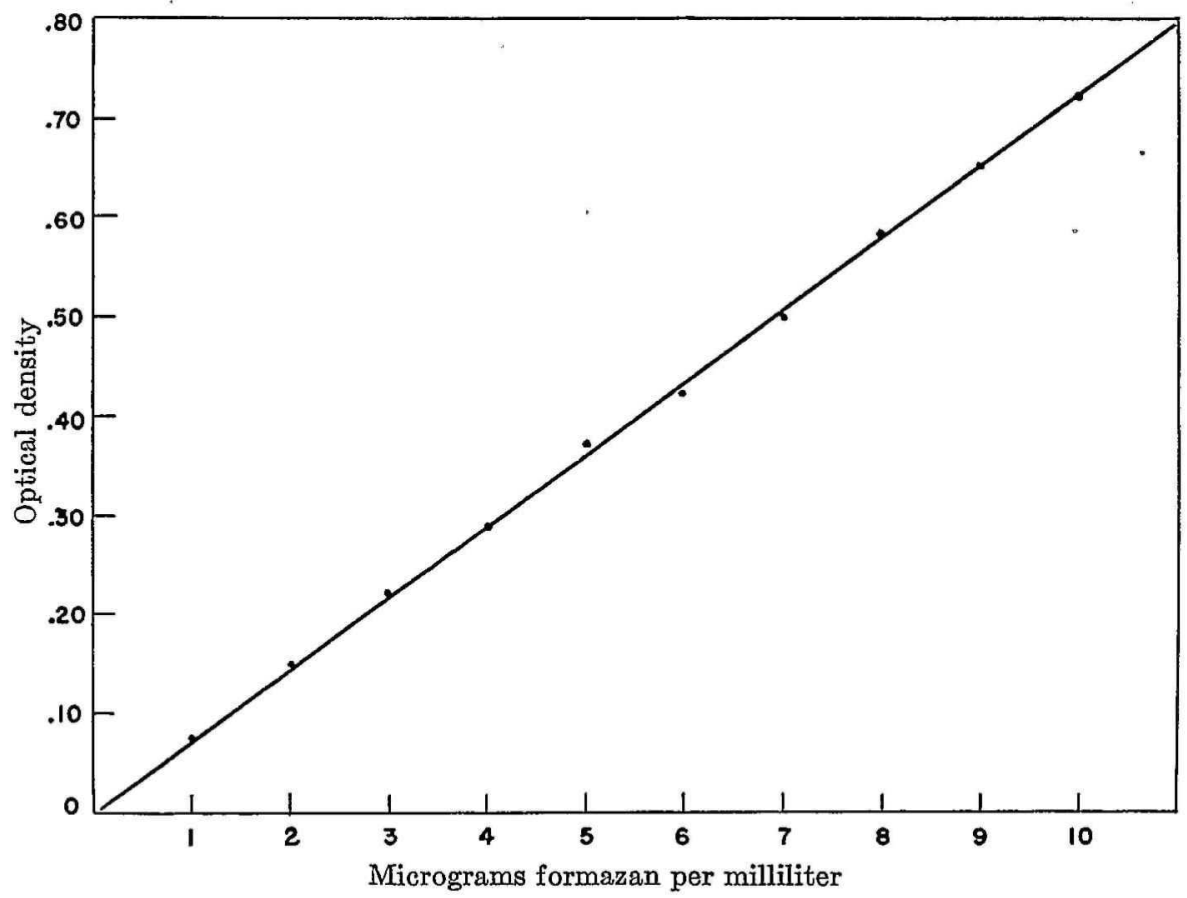

FIG. 1.-Concentration curve of triphenyl formazan.

tetrazolium chloride. The tubes were placed in a constant-temperature bath at $37^{\circ} \mathrm{C}$. for a period of 5 hours.

A similar procedure was used with the extracts of the meristematic tissues of the plants grown under natural day-lengths, and also with portions of both extracts boiled before the addition of the above-mentioned reagents. At the end of 5 hours at $37^{\circ} \mathrm{C}$. the test tubes containing the extracts were removed from the constant-temperature bath and their contents were extracted with acetone.

The formation of triphenyl formazan in the extracts was determined colorimetrically in the spectrophotometer by comparison of their optical density at $490 \mathrm{~m} \mu$ with the concentration curve already prepared. 
TABLE 1.-Average spectrophotometric readings of the optical-density values for triphenyl formazan produced by the extracts of sugarcane meristematic tissues grown under different photoperiods ${ }^{1}$

\begin{tabular}{l|c|c|c}
\hline \multirow{2}{*}{ Light } & \multicolumn{3}{|c}{ Results for extract No-m } \\
\cline { 2 - 4 } & 1 & 2 & 3 \\
\hline Prolonged & $\begin{array}{r}0.440 \\
.265\end{array}$ & $\begin{array}{r}0.451 \\
.320\end{array}$ & $\begin{array}{r}0.485 \\
.283\end{array}$ \\
\hline
\end{tabular}

1 The values are averages of the 6 replicates of each extraction.

TABLE 2.-Micrograms of triphenyl formazan produced per milliliter of solution of the extracts of sugarcane tissues grown under different photoperiods ${ }^{1}$

\begin{tabular}{l|c|c|c}
\hline \multirow{2}{*}{ Light } & \multicolumn{2}{|c}{ Results for extract No- } \\
\cline { 2 - 4 } & 1 & 2 & 3 \\
\hline Prolonged & 6.2 & 6.4 & 6.7 \\
Controls & 3.7 & 4.5 & 4.1 \\
\hline
\end{tabular}

1 The values represent the averages of the 6 samples of each extraction.

\section{RESULTS}

Three extractions of six samples each were made from the tissues of the meristems of the sugarcane grown under extended photoperiods and under natural day-lengths.

In every case the results obtained with the six replicates were almost identical, showing very little variation. All the solutions were light-strawcolored before the test for the activity of the dehydrogenases in them. After the test all the solutions displayed a red coloration, apparently due to the presence of triphenyl formazan formed during the test.

In all cases the intensity of the red color was apparently higher in the extracts of the meristematic tissues of the plants grown under the extended photoperiods.

Table 1 shows an average of the results obtained in the spectrophotometric readings of the three extractions, and table 2 the quantity of triphenyl formazan produced as read on the curve.

Apparently the extracts made from cane under additional periods of light produced more triphenyl formazan, indicating greater dehydrogenase activity.

\section{DISCUSSION}

Some of the responses of sugarcane plants placed under altered photoperiods could possibly be explained on the basis of enzymatic responses of 
the plants to abnormal photoperiods. The results shown in tables 1 and 2 seem to indicate that extended photoperiods either induce an increased activity of the dehydrogenases in the cells of the meristematic regions of the canes, or cause the cells to produce more of these organic catalysts.

That enzymes are affected by the length of the photoperiods has been demonstrated by Knott (9), who found that there is a change in the activity of some enzymes in the growing points of spinach after 2.5, 16.5, and 40.5 hours of light exposure. It has also been shown that since light is the active factor in photoperiodism, some radiations are responsible for changes in the activity of the enzymatic mechanism of several plants (4).

According to Summer and Somers (14), the dehydrogenases are enzymes of "first attack," and they start a series of reactions which lead ultimately to the formation of water. These enzymes are hydrogen removers or hydrogen carriers and consequently induce oxidation. A greater activity of the dehydrogenases means an increase in the rate of respiration.

In sugarcane an increased activity of the dehydrogenases may lead also to a higher rate of over-all metabolism which may finally result in a suppression of blooming and in greater plant growth.

The use of the 2-3-5 triphenyl tetrazolium chloride in this experiment to determine the presence or the activity of the dehydrogenases is based upon the property shown by the solutions of 2-3-5 TTC when reduced by a suitable reducing agent. These solutions turn colorless solutions red by formation of triphenyl formazan when reduction occurs.

The change from 2-3-5 triphenyl tetrazolium chloride to the triphenylformazan is shown by the following reaction:

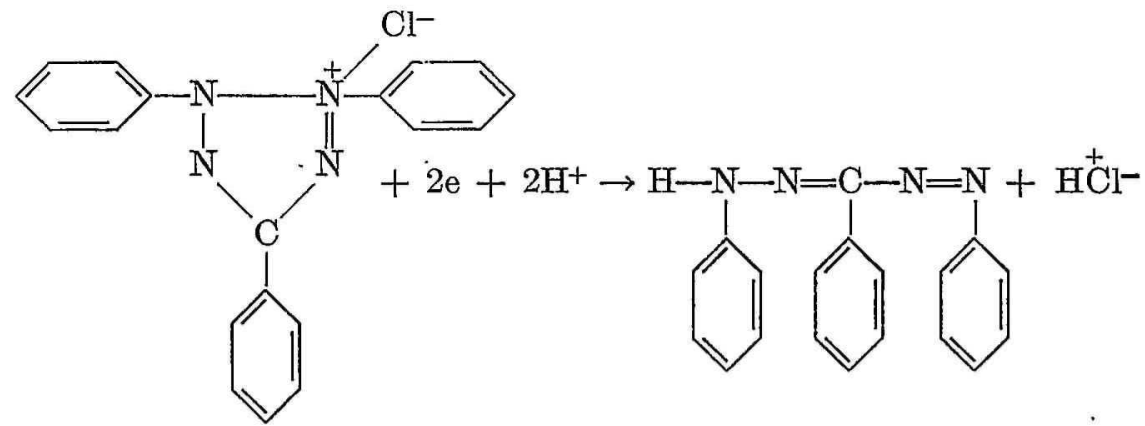

2,3,5 triphenyl tetrazolium chloride

Triphenyl formazan

The apparent redox potential of 2-3-5 triphenyl tetrazolium chloride is about -0.8 volt; thus it is possible for this compound to act as an electron acceptor for many dehydrogenases (6).

It seems that the dehydrogenases present in sugarcane tissues reduced the 2-3-5 triphenyl tetrazolium chloride, which here acted as a hydrogen 
acceptor for the hydrogen from the substrate, producing more intensely colored solutions of triphenyl formazan in the extracts from the meristematic tissues of the sugarcanes grown under additional periods of light.

That the increase in reduction of the 2-3-5 triphenyl tetrazolium chloride in this experiment was caused by an enzyme and not by sugars or other reducing agents was shown by the results obtained with the boiled extracts before the reduction test. The boiled extracts showed negative results, indicating that the enzymes had been irreversibly destroyed by heating.

\section{SUMMARY}

From the results obtained in the present investigation and from many more similar reports it is possible to conclude that, apparently, extended photoperiods induce either a higher activity of the dehydrogenases present, or an increase in the content of these enzymes in the cell of the apical meristems of sugarcane plants.

It also appears that the conditions controlling the activity of the meristems are limited somewhat by the enzymatic activity of the cells of the meristems.

Though there is no evidence as yet to support a theory regarding the enzymatic control of the floral mechanism, the apparently higher metabolic activity induced by a higher content, or increased activity of the enzymes in the cells, and the prolongation of the vegetative condition of the meristematic cells, seem to be interrelated with and dependent upon the photoperiods.

\section{RESUMEN}

La presente investigación con la caña de azúcar señala que cuando se prolongan los períodos de luz a la planta se registra una mayor actividad de las dehidrogenasas o hay un aumento en el contenido de estas enzimas en las células del tejido meristemático.

Se ha podido deducir de la investigación que las condiciones que controlan la actividad de los meristemios están limitadas, hasta cierto punto, por la actividad enzimática de dichos tejidos.

Aunque no hay evidencia aún para respaldar la teoría que relaciona el control del mecanismo floral por medio de las enzimas, la aparente mayor actividad metabólica inducida por un contenido más alto, o por una actividad mayor de éstas, así como la prolongación del estado vegetativo de las células meristemáticas, parecen estar relacionados con y depender de los fotoperíodos.

\section{LITERATURE CITED}

1. Brown, H. T. and Moriss, G. W., A contribution to the chemistry and physiology of foliage leaves, J. Chem. Soc. Trans. IXIII, 1893. 
2. Coville, F. V., The influence of cold in stimulating the growth of plants, J. Agr. Res. 20 151-60, 1920.

3. Glock, E., The succinic dehydrogenase of avena seeds and seedlings as determined colorimetrically with diphenylene bis (diphenyl tetrazolium chloride), M. Sc. Thesis, Pa. State College, State College, Pa., 1952.

4. Green-Windisch, T. R., Die Enzyme, Berlin, 1901.

5. Isemberg, F. H. R., Odland, M. L., Popp, H. W., and Jensen, C. O., The effect of maleic hydrazide on certain dehydrogenases in tissues of onion plants, Sci. $11358-60,1951$.

6. Jensen, C. O., Sacks, W., and Baldauski, F. A., The reduction of triphenyl-tetrazolium chloride by dehydrogenases of corn embryo, Sci. 113 65-6, 1951.

7. Knott, G. E., Further localization of the response in plant tissue to relative length of day and night, Proc. Amer. Soc. Hort. Sci. 23 67-70, 1926.

8. Catalase in relation to growth and other changes in plant tissues, Cornell Univ. Agr. Exptl. Sta., Ithaca, N. Y., Memo. 106, 1927.

9. - Rapidity of response of spinach to changes in photoperiodism, Plant Physiol. 8 125-30, 1932.

10. Krassinsky, N., On photoperiodism and changes in the enzymatic systems, Ann. of Bot. (London) 50 293-304, 1936.

11. Ljubimenło, V. N. and Sceglova, O., On photoperiodical adaptation, J. Russian Bot. Soc. 12 113-59, 1927.

12. Mattson, A. M., Jensen, C. O., and Dutcher, R. A., The preparation of 2-3-5 tripheyl tetrazolium chloride, J. Am. Chem. Soc. 70 1284, 1948.

13. Miller, J. C., A study of some factors affecting seed stalk development in cabbage, Cornell Univ. Ag. Expt. Sta., Ithaca, N. Y., Bull. 788, 1929.

14. Summer, J. B. and Somers, C. F., Chemistry and methods of enzymes, Academic Press Inc., New York, N. Y., 1947.

15. White, D. G., Blossoming of fruits delayed by maleic hydrazide, Sci. 111 313, 1950. 